\title{
Haemangioendothelioma (Kupffer cell angiosarcoma), myelofibrosis, splenic atrophy, and myeloma paraproteinaemia after parenteral thorotrast administration
}

\author{
R. C. JENNINGS AND S. E. PRIESTLEY \\ From Altrincham General Hospital, Cheshire, UK
}

SUMMARY A case of thorotrastosis occurred 25 years after thorotrast angiography, with the previously unrecorded association of myeloma type paraproteinaemia. The relationship between haemangioendothelioma due to thorotrast and other vascular sarcomas of the liver is briefly reviewed.

Thorotrast, a $20 \%$ colloidal solution of thorium dioxide-232 $\left({ }^{232} \mathrm{ThO}_{2}\right)$ was used as a contrast medium in clinical radiography from 1930 until 1953 (Janower et al., 1968). Because of its greater clarity compared with other contrast media available at that time and the absence of vascular and allergic reactions it became widely used in arteriography, hepatolienography, and outlining of body cavities (Dahlgren, 1961).

Once administered parenterally, thorotrast is rapidly removed from the circulation by the phagocytic cells of the reticuloendothelial system (RES). Approximately $70 \%$ is taken up by the liver, $20 \%$ by the spleen, and the remainder by the bone marrow and lymph nodes (Janower et al., 1968).

Because ${ }^{232} \mathrm{ThO}_{2}$ has a long biological half-life, about $\mathbf{4 0 0}$ years, and because its radioactive decay emits mainly alpha radiation (Gondos, 1973), the cells of the RES where the thorium is deposited are subjected indefinitely to continuous low-dose irradiation. The effects of this permanent retention are probably twofold: a physicochemical one causing progressive tissue fibrosis, and an added local irradiation effect, which may eventually induce neoplastic changes (Boyd et al., 1968).

Although malignancy had been reported in laboratory animals injected with thorotrast by Selbie as early as 1936, it was not until 1947 that MacMahon et al. reported the first human malignant case due to thorotrast, an endothelial-cell sarcoma of the liver occurring 12 years after parenteral adminis-

Received for publication 7 June 1978 tration. Since this initial report further cases of haemangioendothelioma of the liver have been recorded. Less frequently, epithelial hepatic tumours attributable to thorotrast have been reported and, in some instances, local thorotrastoma at the site of thorotrast injection (Horta, 1973).

There is a long latent period from the injection of thorotrast until the development of malignancy, and although this varies from two to 31 years, according to the series, a mean of 21 years is generally accepted (Horta et al., 1965; Boyd et al., 1968).

\section{Case report}

A 74-year-old Caucasian woman was admitted to hospital in a poor condition with a two months' history of progressive lethargy, anorexia, and weight loss of $11 \mathrm{~kg}(24 \mathrm{lb})$. She had been investigated by a urologist three months previously for a single episode of haematuria and renal colic but no explanation for this was found. A full blood count, serum urea and electrolytes, calcium and phosphorus, urine microscopy, cystoscopy, and an intravenous pyelogram were all normal. An abdominal $x$-ray at that time showed a curious unexplained opacification of the spleen, liver, and lymph nodes at the porta hepatis (Fig. 1).

On physical examination she was apyrexial and appeared cachectic with pale mucosae and icteric sclera. No other abnormalities were detected and, in particular, there was no purpura, lymphadenopathy, or hepatosplenomegaly. She rapidly deteriorated after admission and died 18 hours later. 


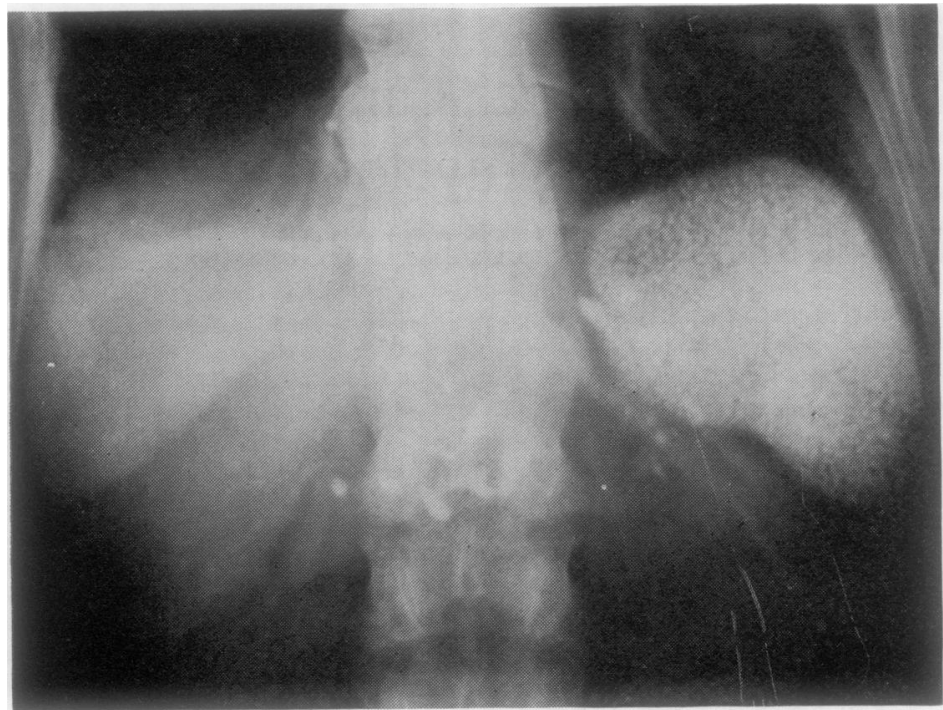

Fig. 1 Plain abdominal x-ray showing opacification of the spleen, liver, and lymph nodes at the porta hepatis.

The following investigations were carried out: Hb $9.4 \mathrm{~g} / \mathrm{dl}$; RBCs $2.6 \times 10^{12} / 1\left(2.6 \times 10^{6} / \mu \mathrm{l}\right)$; PCV 0.27; MCH $36 \mathrm{pg}$; MCHC $35 \mathrm{~g} / \mathrm{dl}(35 \%)$; MCV 110 fl $\left(110 \mu^{3}\right) ;$ WBC $22 \times 10^{9} / 1(22000 / \mu l)$. The differential count showed $82 \%$ neutrophils, $6 \%$ lymphocytes, $6 \%$ monocytes, $2 \%$ myelocytes, and $3 \%$ metamyelocytes. There were multiple red cell abnormalities including anisocytosis, poikilocytosis, schistocytosis, and numerous nucleated red cells $(19 / 100$ white cells) of megaloblastic type, many showing Howell-Jolly bodies. The platelets were reduced at $12 \times 10^{9} / 1(12000 / \mu \mathrm{l})$ and the reticulocytes were increased to $7 \cdot 6 \%$. The urea, electrolytes, blood creatinine, glucose, serum $B_{12}$, and serum folate were normal. The bilirubin was $100 \mu \mathrm{mol} / 1$ $(5.8 \mathrm{mg} / \mathrm{dl})$ and the alkaline phosphatase increased to $273 \mathrm{IU} / 1 / 37^{\circ} \mathrm{C}$. Isoenzyme electrophoresis showed this increase to be due to enzymes of liver type. The thymol turbidity was increased to 7 units but the transaminases were within normal limits, the AST $27 \mathrm{IU} / 1 / 37^{\circ} \mathrm{C}$ and ALT $23 \mathrm{IU} / 1 / 37^{\circ} \mathrm{C}$. The total serum protein was normal in amount $(72 \mathrm{~g} / 1(7 \cdot 2 \mathrm{~g} / \mathrm{dl}))$, but there was a relative increase of the globulin ( 40 $\mathrm{g} / \mathbf{1}(4.0 \mathrm{~g} / \mathrm{dl}))$. A monoclonal band of gamma globulin was found on electrophoresis of the serum, which was confirmed when a quantitative immunoglobulin estimation showed an increased IgM (15.75 $\mathrm{g} / \mathrm{l}(1.58 \mathrm{~g} / \mathrm{dl})) ; \mathrm{IgG}$ and IgA were normal. A chest $x$-ray was normal but the skull $x$-ray showed two punched out translucent areas over the left posteroparietal region (Fig. 2).

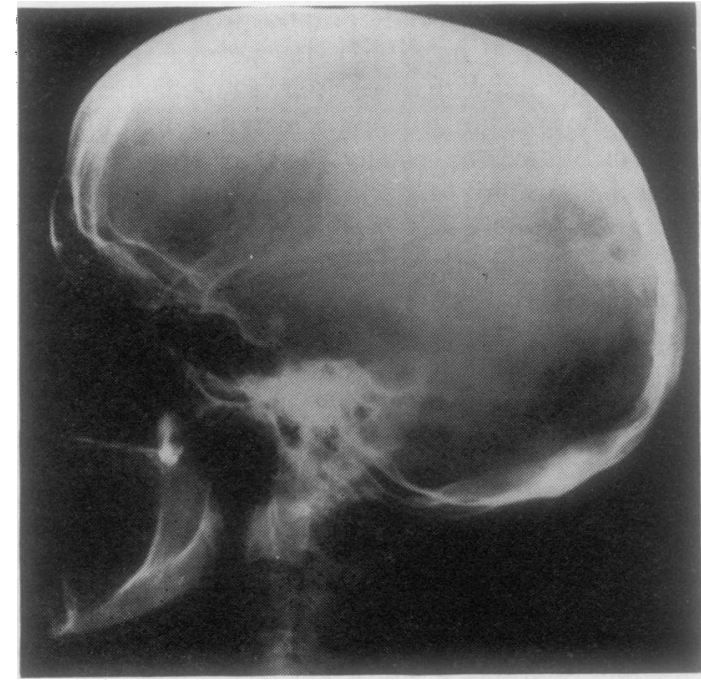

Fig. 2 Skull $\mathrm{x}$-ray showing translucent areas in the left posteroparietal region.

Subsequent to her death information was obtained showing that in 1952 she had been given $45 \mathrm{ml}$ of thorotrast for a carotid angiogram as part of the investigations of a brain tumour; no abnormality was detected at that time. The radiological changes in the spleen, liver, and lymph nodes were typical of those that follow parenteral administration of thorotrast (Gardner and Ogilvie, 1959). 


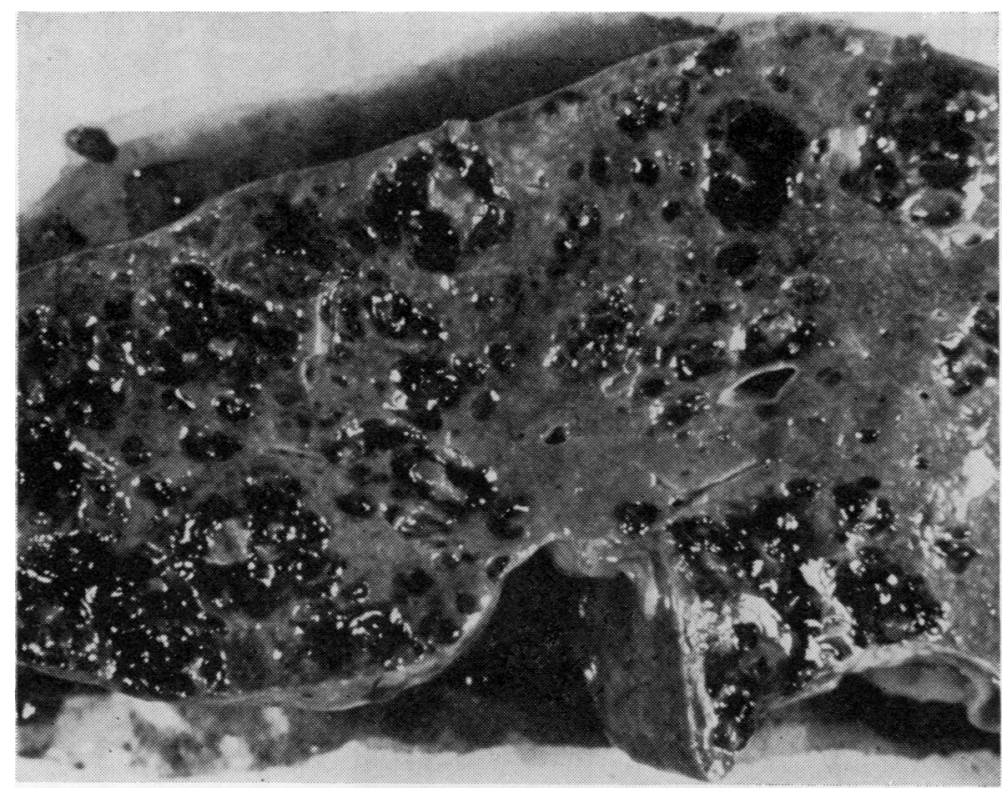

Fig. 3 Liver showing muliple haemorrhagic cysts with residual intervening parenchyma.

\section{PATHOLOGY}

\section{Necropsy}

The body was that of a thin, elderly woman with scattered bruising of the trunk and limbs. There was no external adenopathy.

A diffuse, terminal, subdural haemorrhage was present over both cerebral hemispheres but there was no intraparenchymatous haemorrhage. The two osteolytic lesions in the left parietal region were identified. The lungs and heart $(260 \mathrm{~g})$ were essentially normal in appearance. The liver weighed $1540 \mathrm{~g}$ and showed a generalised haemorrhagic cystic appearance involving both lobes. The cysts were of varying size from 1 to $20 \mathrm{~mm}$ in diameter with residual parenchyma between them (Fig. 3). The spleen weighed $170 \mathrm{~g}$ and showed capsular thickening. On section there were multiple small $(2-3 \mathrm{~mm})$, firm, yellow nodules scattered throughout the parenchyma with one or two larger similarly coloured lesions.

The thyroid was firmer than normal on section but not enlarged. There were no other relevant findings.

\section{Histology}

The liver showed prominent thorotrast pigment deposition, mainly in the portal tracts and to a lesser extent scattered throughout the parenchyma with a variable amount of intervening normal hepatic tissue. Multiple blood-containing cysts were present which at their inception were lined by a single layer of phagocytic tumour cells and as they enlarged showed both solid and papillary intracystic tumour cell groups (Fig. 4). Although giving a pseudoepithelial appearance in parts they were clearly mesenchymal in origin. The cells were polygonal or elongated in shape with a loose-textured, mainly centrally situated nucleus, and plentiful cytoplasm (Fig. 5). The latter often contained pigment granules (Fig. 6) but there was no evidence of erythrophagocytosis. The pigment was refractile, slightly brownish in colour, with no positive staining with haematoxylin and eosin, van Gieson, Masson's trichrome, Martius scarlet blue, Perl's prussian blue, and periodic acid-Schiff.

The spleen showed pronounced pigment deposition (Fig. 7). Between the large focal groups of pigment granules there was a fibrosing cellular parenchyma with some necrosis but virtually no residual normal splenic tissue. These areas showed varying cellular activity, phagocytic histiocytes predominating, but with some plasma cell groups, much haemorrhage, and evidence of extramedullary erythropoiesis. Some of the hyperplastic phagocytic areas were particularly cellular and suggested possible early malignant change. A few parts contained eosinophilic material staining positively for amyloid (Congo red, methyl violet, and thioflavin T).

The parietal bone showed two haemorrhagic cystic lesions with plasma cell groups within the 


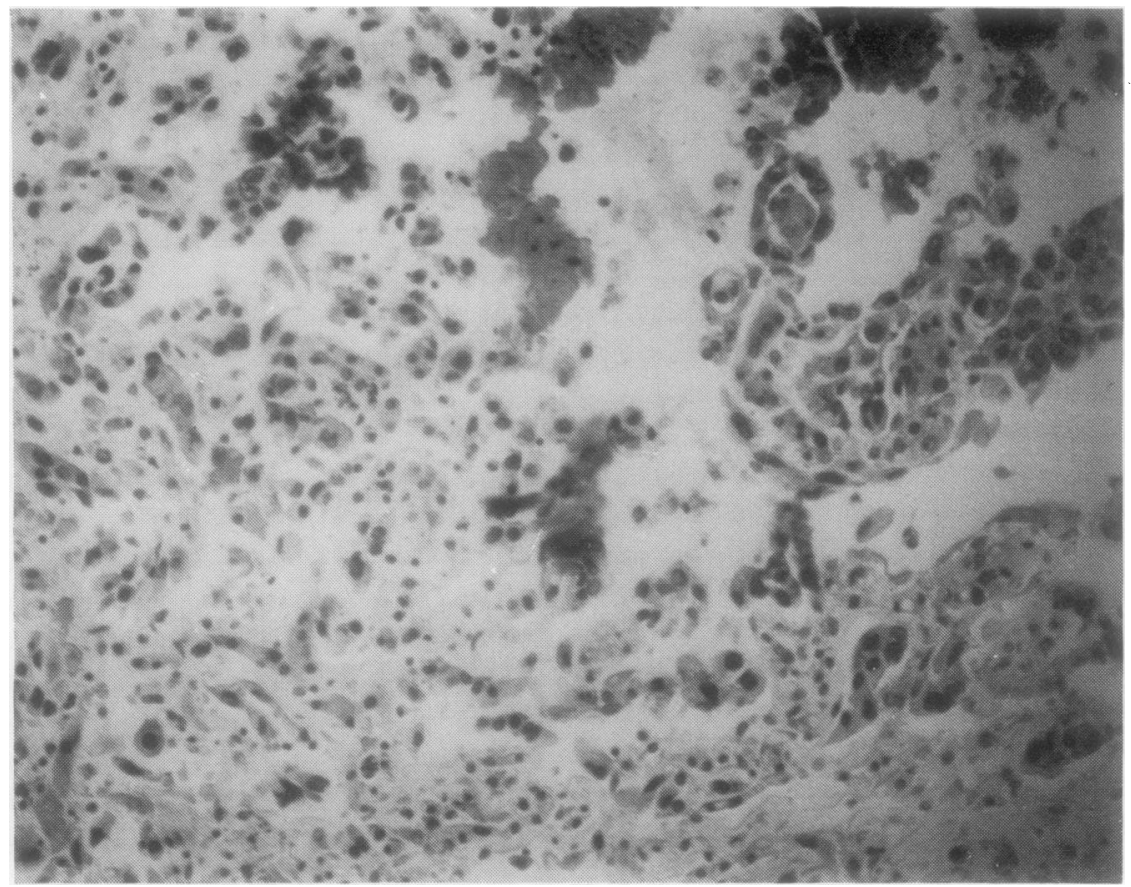

Fig. 4 Intracystic proliferation of tumour cells with surrounding liver parenchyma showing some infiltration.

(Haematoxylin and $\operatorname{eosin} \times 125$ )

$\overrightarrow{0}$ 응 구 要.

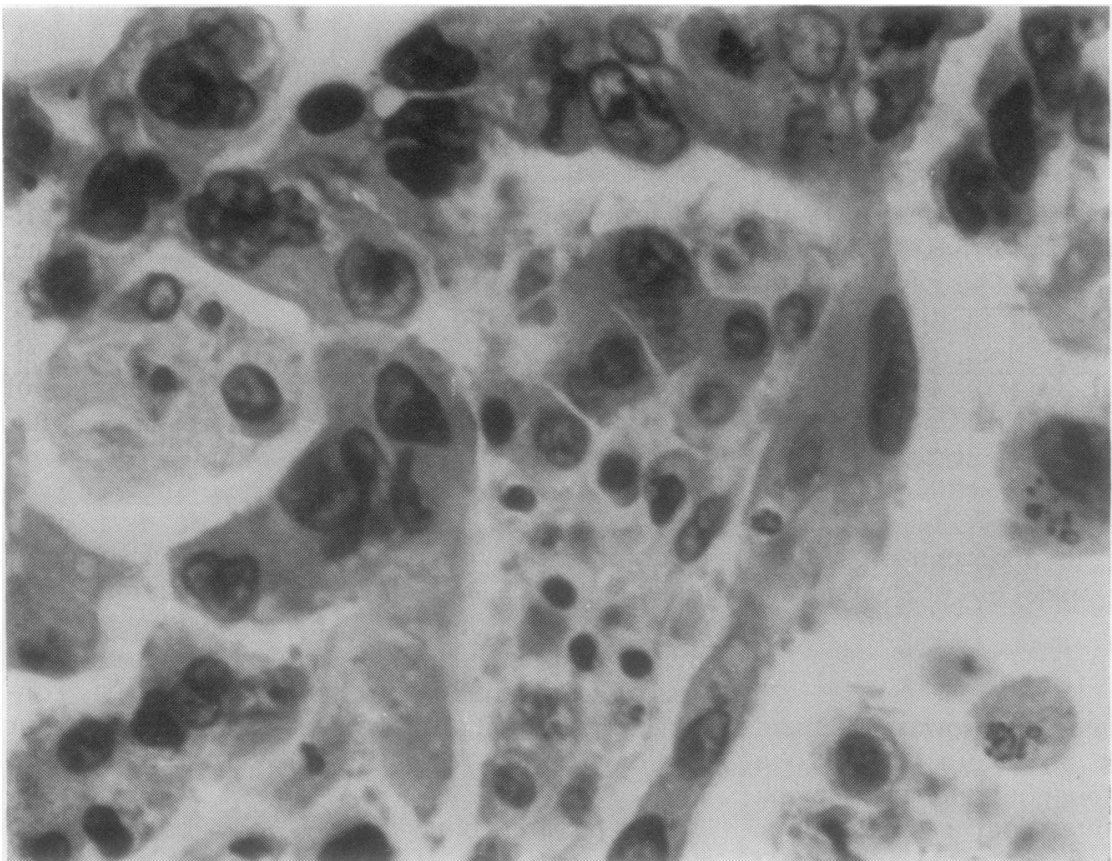

Fig. 5 Polygonal and elongated tumour cells, some showing intracytoplasmic pigment. (H and $E \times 500)$ 


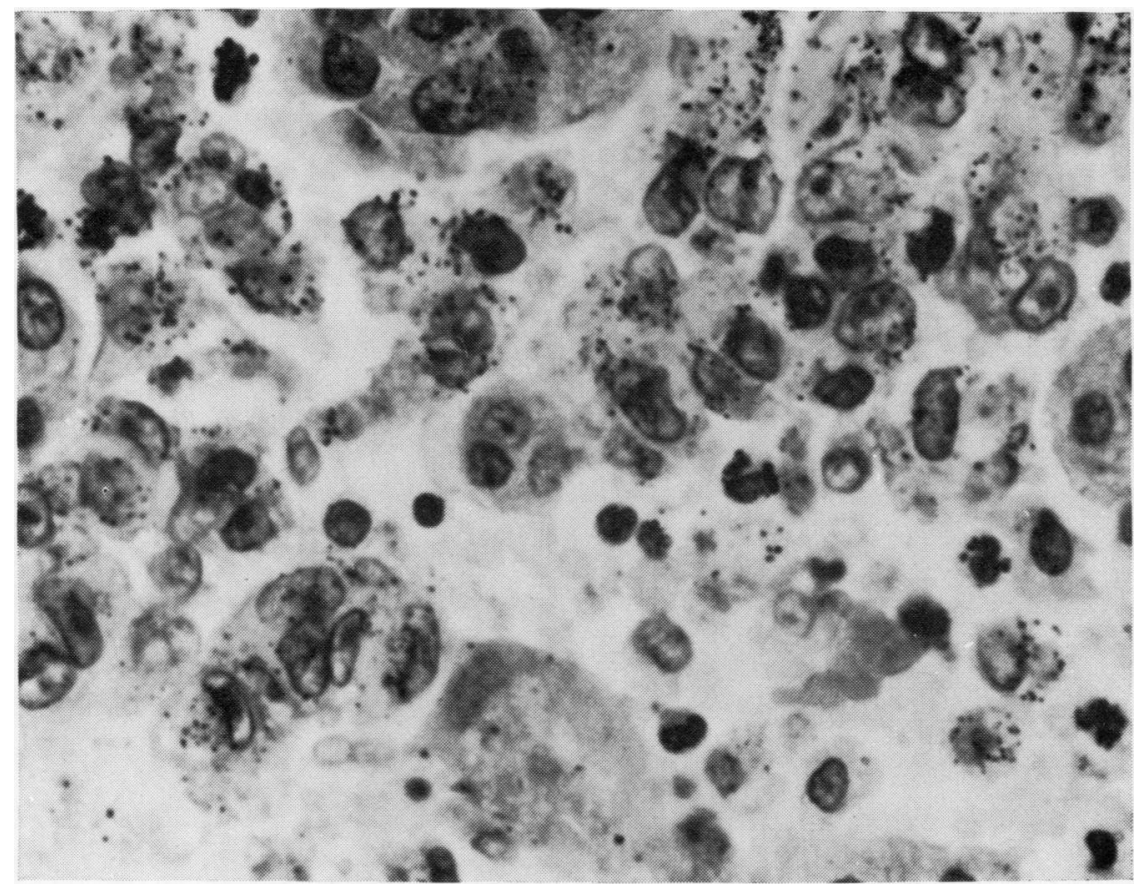

Fig. 6 Area of tumour showing prominent intracytoplasmic pigment.

( $H$ and $E \times 500)$

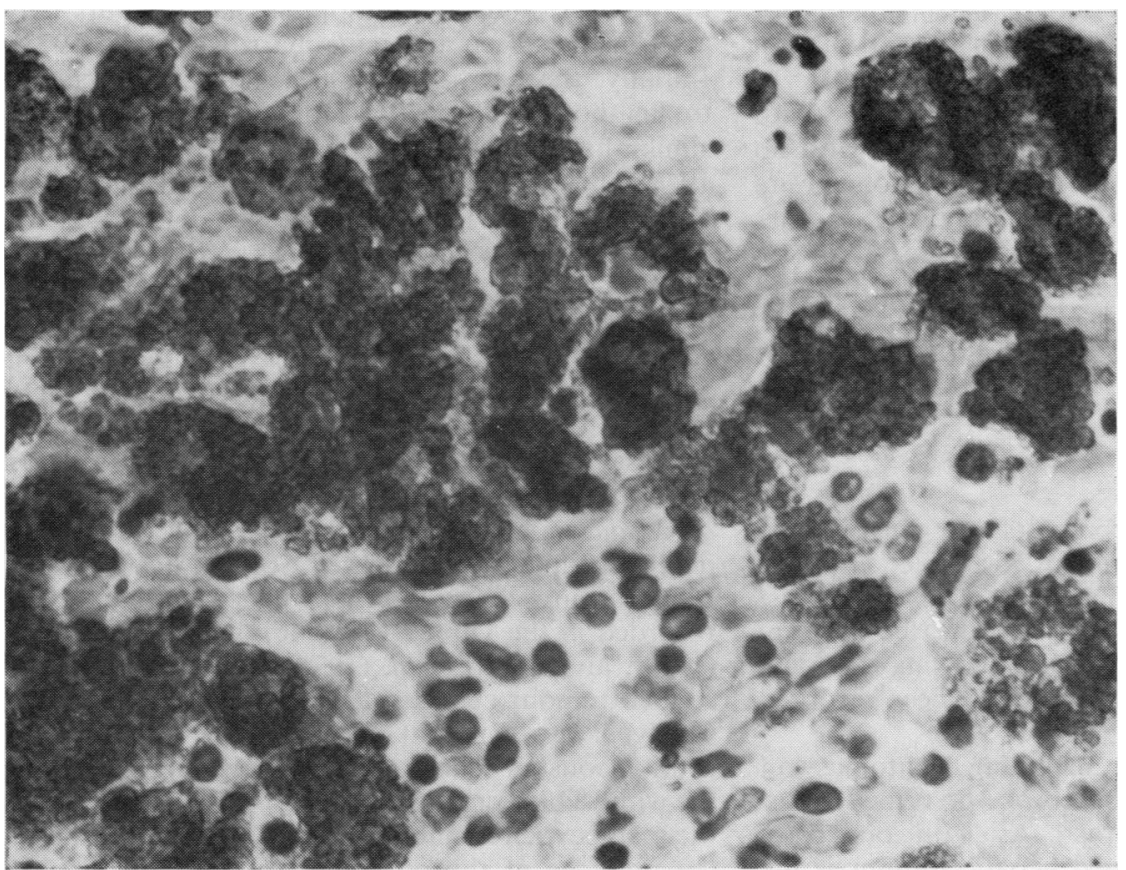

Fig. 7 Dense aggregates of thorotrast in the spleen. ( $H$ and $E \times 500$ ) 


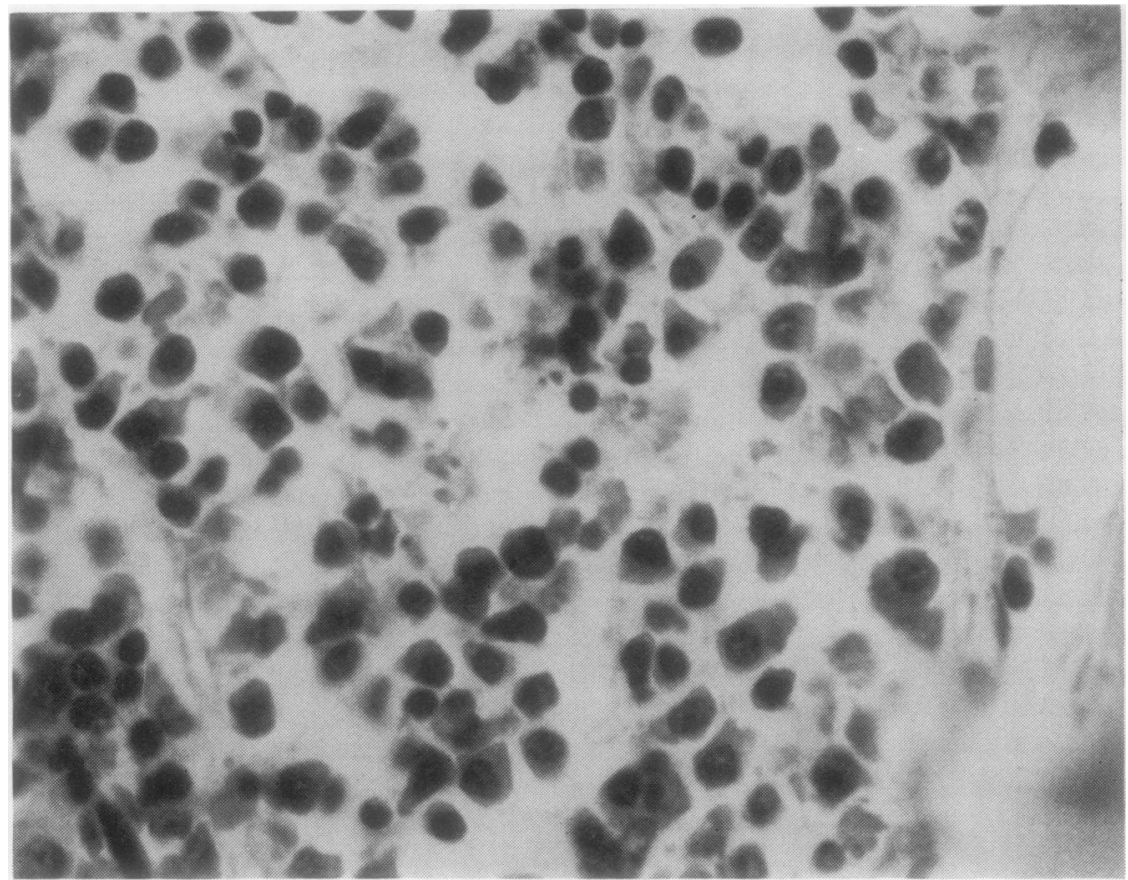

Fig. 8 Plasma cells in the cystic area of the skull.

( $H$ and $E \times 500)$

cystic spaces (Fig. 8). The bone marrow from the sternum and iliac crest showed some pigment deposition with alternating areas of hyperplasia and myelofibrosis and, in addition, focal aggregates of plasma cells.

There was a diffuse chronic thyroiditis with reduction in colloid acinar production but with no pigment deposition. The other organs sectioned were normal and there was no pigment present in other sites and no evidence of tumour metastases.

The final diagnosis was of a thorotrast-induced multifocal hepatic haemangioendothelioma (Kupffer cell angiosarcoma) with splenic atrophy, myelofibrosis, and myeloma.

\section{Discussion}

The use of thorotrast represents the only human parenteral radiation experiment available. The case described, presenting 25 years after thorotrast angiography, illustrated many of the features reported in the literature, as well as showing myeloma with paraproteinaemia, which has not been recorded previously.

Various hepatic tumours, including hepatomas and cholangiocarcinomas, have been described after administration of thorotrast. As with our case, the most frequently reported hepatic tumour is the haemangioendothelioma (Selinger and Koff, 1975). This tumour is thought to be multicentric in origin in the liver, and, in addition, similar tumours may arise in the spleen and bone marrow (Horta, 1973). Initially, the haemangioendothelioma was believed to be thorotrast-specific (Horta et al., 1965), but similar tumours can arise spontaneously (Baker et al., 1956). These authors presented good evidence that the tumours they described were Kupffer cell in origin and showed phagocytosis. They had vasoformative characteristics because of the endothelial anatomical location of Kupffer cells within the sinusoids of the hepatic lobules. The more recent association of angiosarcoma of the liver with vinyl chloride exposure (Baxter et al., 1977) is also of interest in this connection. This association was reviewed in the Proceedings of the Royal Society of Medicine, where Weinbren (1976) described in detail a primary angiosarcoma of the liver attributable to vinyl chloride. Two other cases have been recorded in the United Kingdom by Lee and Harry (1974), and Smith et al. (1976), and the latter described tumour cells as being of malignant Kupffer cell type. It seems that the thorotrast tumours, the spontaneously occurring Kupffer cell sarcomas, and the vinyl chloride induced ones all originate from the phagocytic reticuloendothelial (Kupffer) cell, but the presence of thorotrast may modify to some ex- 
tent the histological appearances. The term haemangioendothelioma is probably a misnomer as these tumours are not arising from true vascular endothelium but from phagocytic reticuloendothelial cells possessing vasoformative properties. The term angiosarcoma alone also indicates definite vascular origin, which is uncertain, and Kupffer cell angiosarcoma seems preferable as it indicates not only the basic character of the lesion but the likely cell of origin.

The combined fibrogenic and irradiation effects of thorotrast on the bone marrow have been well described (Bastrup-Madsen and Jensen, 1971; Johnson et al., 1977). These include leukaemia, marrow aplasia, thrombocytopenia, Di Guglielmo's syndrome, and myelofibrosis. It is a combination of the latter with splenic atrophy (caused by the fibrogenic nature of thorotrast) that produces the polymorphic peripheral blood picture (Langlands and Williamson, 1967). In our patient, the peripheral blood film showed fragmented red cells including schistocytes with erythroblastosis and prominent Howell-Jolly bodies. The thrombocytopenia present could explain the terminal subdural haemorrhage and exaggerate the haemorrhagic tendency in the liver and spleen.

The present case showed bony myelomatous deposits together with a paraproteinaemia. Two osteolytic lesions were present in the skull and histologically showed dilated vascular spaces containing groups of plasma cells. In addition, focal groups of plasma cells were present in other parts of the bone marrow. Horta, in 1967, described both plasma cell increase in the spleen and bone marrow and referred to cases of 'dysproteinaemia' with increased alpha-2 and gamma globulin, but none was of monoclonal type. Bethlenfalvay et al. (1976) described a non-secretory plasma cell dysplasia which terminated in acute leukaemia 25 years after thorotrast administration. There is no previous case recorded with a monoclonal gammopathy. This is perhaps surprising as the chronic irritative effect upon the RES might be expected to stimulate abnormal plasma cell clonal activity.

The presence of amyloid material in the spleen could possibly be attributed to a chronic granulomatous aetiology rather than to the myelomatous process. Horta (1967) described an amorphous eosinophilic substance in the thorotrast-affected spleen, and although the usual amyloid stains were carried out by him, the spleen did not show any positive amyloid staining.

The diffuse chronic thyroiditis present may be a chance finding but it could possibly reflect the hyperplastic reticuloendothelial effect. Other authors (Langlands and Hermann, 1967) have reported an increased incidence of thyrotoxicosis after parenteral thorotrast administration.

Much of the thorotrast story is now of historical interest only, but, owing to the long latent period before the development of complications, new cases are still presenting. They serve as a salutary reminder of the mistakes made in the past, but, in spite of this, as recently as 1975 a case was being put forward for the reintroduction of thorotrast as a contrast medium for the visualisation of brain stem abscesses (Robert et al., 1975).

We thank Dr J. Davson, Dr F. Lee, and Professor P. J. Scheuer for their helpful advice, Dr C. D. R. Pengelly for permission to publish details of the case, and Christine Marsden and Judy White for invaluable secretarial help.

\section{References}

Baker, H. de C., Paget, G. E., and Davson, J. (1956). Haemangio-endothelioma (Kupffer-cell sarcoma) of the liver. Journal of Pathology and Bacteriology, 72, 173-182.

Bastrup-Madsen, P., and Jensen, B. N. (1971). Myelofibrosis with myeloid metaplasia and pancytopenia after thorotrast injection. Acta Medica Scandinavica, 189, 355-358.

Baxter, P. J., Anthony, P. P., MacSween, R. N. M., and Scheuer, P. J. (1977). Angiosarcoma of the liver in Great Britain, 1963-73. British Medical Journal, 2, 919-921.

Bethlenfalvay, N. C., Henley, L. B., Rupp, T. D., and Phyliky, R. L. (1976). Nonsecretory plasma cell dyscrasia followed by acute granulocytic leukaemia 25 years after Thorotrast administration. Cancer, 37, 1449-1453.

Boyd, J. T., Langlands, A. O., and Maccabe, J. J. (1968). Long-term hazards of Thorotrast. British Medical Journal, 2, 517-521.

Dahlgren, S. (1961). Thorotrast tumours: a review of the literature and report of two cases. Acta Pathologica et Microbiologica Scandinavica, 53, 147-161.

Gardner, D. L., and Ogilvie, R. F. (1959). The late results of injection of thorotrast: two cases of neoplastic disease following contrast angiography. Journal of Pathology and Bacteriology, 78, 133-144.

Gondos, B. (1973). Late clinical and roentgen observations following thorotrast administration. Clinical Radiology, 24, 195-203.

Horta, J. da Silva (1967). Late effects of Thorotrast on the liver and spleen and their efferent lymph nodes. Annals of the New York Academy of Sciences, 145, 676-699.

Horta, J. da Silva (1973). Tumours developed in people injected with thorium dioxide (Thorotrast) (Portuguese experience). Proceedings of the 3rd International Meeting on the Toxicity of Thorotrast. Riso Reports, 294, 233-248.

Horta, J. da Silva, Abbatt, J. D., da Motta, L. C., and 
Roriz, M. L. (1965). Malignancy and other late effects following administration of thorotrast. Lancet, 2, 201205.

Janower, M. L. Sidel, V. W., Baker, W. H., Fitzpatrick, D. E. P., Guarino, F. I., and Flynn, M. J. (1968). Late clinical and laboratory manifestations of thorotrast administration in cerebral arteriography. New England Journal of Medicine, 279, 186-189.

Johnson, S. A. N., Bateman, C. J. T., Beard, M. E. J., Whitehouse, J. M. A., and Waters, A. H. (1977). Long term haematological complications of Thorotrast. Quarterly Journal of Medicine, 46, 259-271.

Langlands, A. O., and Hermann, K. (1967). Thyroid disease following the administration of Thorotrast. Journal of Clinical Pathology, 20, 892-895.

Langlands, A. O., and Williamson, E. R. D. (1967). Late changes in peripheral blood after Thorotrast administration British Medical Journal, 3, 206-208.

Lee, F. I. and Harry, D. S. (1974). Angiosarcoma of the liver in a vinyl-chloride worker. Lancet, 1, 1316-1318. MacMahon, H. E., Murphy, A. S., and Bates, M. I.
(1947). Endothelial-cell sarcoma of liver following thorotrast injections. American Journal of Pathology, 23, 585-611.

Robert C. M., Jr., Stern, W. E., Brown, W. J., Greenfield, M.A., and Bentson, J. R. (1975). Brain stem abscess treated surgically, with special note upon the employment of thorium dioxide. Surgical Neurology, 3, 153-160.

Selbie, F. (1936). Experimental production of sarcoma with thorotrast. Lancet, 2, 847-848.

Selinger, M., and Koff, R. S. (1975). Thorotrast and the liver: a reminder. Gastroenterology, 68, 799-803.

Smith, P. M., Williams, D. M. J., and Evans, D. M. D. (1976). Hepatic angiosarcoma in a vinyl chloride worker. Bulletin of the New York Academy of Medicine, 52, 447-452.

Weinbren, K. (1976). Histopathology of liver lesions associated with exposure to vinyl chloride monomer. Proceedings of the Royal Society of Medicine, 69, 299-303. 